\title{
The Role of Professional Auditor Skepticism and Red Flag Understanding in Assessing Risk of Fraud: An Experimental Study
}

\author{
Ni Made Wisni Arie Pramuki ${ }^{1}$, Komang Ary Pratiwi ${ }^{2}$, Putu Atim Purwaningrat ${ }^{3}$, \\ I Gede Aryana Mahayasa ${ }^{4}$ \\ \{wisniariepramuki@gmail.com ${ }^{1}$, arypratiwikm@gmail.com ${ }^{2}$, atimningrat@gmail.com ${ }^{3}$, \\ aryanamahayasa@gmail.com $\left.{ }^{4}\right\}$
}

Universitas Hindu Indonesia, Denpasar, Bali, Indonesia ${ }^{1,2,3,4}$

\begin{abstract}
This study aims to examine the level of skepticism of professional auditors and the understanding of red flags in detecting fraud. Professional auditor's skepticism as an internal auditor factor and understanding red flags as an external auditor factor. This study uses a 2x2 factorial design between subjects. Professional skepticism and understanding of red flags are manipulated at 2 levels namely high and low professional skepticism and high and low understanding of red flags. The experimental subjects were 60 undergraduate accounting students who had studied the auditing process. ANOVA is applied as a tool to test hypotheses. The results show that fraud risk assessment is influenced by professional auditor skepticism and understanding of red flags.
\end{abstract}

Keywords: professional auditor skepticism, red flags understanding, fraud risk assessment

\section{Introduction}

Fraud in financial statements becomes an endless issue. This can have an impact on several parties or stakeholders so that it becomes the main concern of external auditors. The latest scandal that occurred in Indonesia is the freezing of PT Garuda Indonesia (Persero) 's public auditor permit permits. The Ministry of Finance imposed sanctions on Kasner Sirumapea Public Accountants in the form of a freeze for 12 months, whereas Kasner Public Accountant was one of the two auditors of PT Garuda Indonesia (Persero) financial year 2018 which was considered odd. Kasner Sirumapea is proven to have committed a serious violation that has the potential to significantly influence the opinion of the Internal Auditor's Report. On the other hand, Kasner Sirumapea also has not fully complied with Auditing Standards (SA)Professional Standards for Public Accountants (SPAP), namely SA 315 identification and assessment of the risk of material misstatement through an understanding of the entity and its environment, SA 500 related to audit evidence and SA 560 events later.

Even the phenomenon of fraud in financial reporting is the center of attention of the Indonesian Institute of Certified Public Accountants (IAPI). IAPI regulates fraud risk assessments for external auditors by issuing Section 240 Audit Standards which state that the external auditor's responsibility to obtain a reasonable guarantee that the financial statements are free from material misstatements is either due to fraud or errors. This standard asserts that the risk of not detecting material misstatement due to fraud is higher than the risk of not detecting material misstatement from errors.

Previous research has documented several factors that influence fraud risk assessment. [1] revealed that auditor experience and competence influence the effectiveness of fraud risk assessments. More experienced auditors will have a more effective fraud risk assessment using analytical procedures [1]. Effective communication within the audit team is also another factor that influences the effectiveness of fraud risk assessments. [2] argues that audit team brainstorming improves the quality of fraud risk assessments, especially when fraud occurs. In addition to competence and communication, auditor professional skepticism is an important factor influencing fraud risk assessment [3]. [4] explains that auditor's knowledge and character are related to their level of professional skepticism. Auditors who lack experience and during their careers have never found cheating, professional skepticism becomes very important [5]. 
[6]) using experimental methods prove that auditors with high professional skepticism behave differently from low professional skepticism in evaluating evidence related to the symptoms of fraud. This finding is also supported by [7] who proves that auditor professional skepticism is consistent in predicting the symptoms of fraud. In other words, the auditor seeks more audit evidence and is able to identify more misstatements or contradictory information that usually leads to misstatements of information or symptoms of fraud.

However, different results were shown by [8] who stated that the level of professional skepticism of internal auditors cannot influence their professional judgment in detecting fraud during fraud risk assessment. [9] found that although the auditor recognized the importance of skepticism, the auditor did not show the right level of skepticism when assessing the risk of fraud. Therefore, efforts are needed to increase professional skepticism, such as continuing education about fraud and emphasizing the importance of skepticism at the audit firm level. This finding was also supported by [10]. Through a survey of 63 external auditors in KAP in Yogyakarta and Surakarta, the results were obtained that the auditor's professional skepticism has not been able to make the auditor suspect an indication of fraud from the client and subsequently made auditor skepticism less provoked to increase and trigger efforts to work harder in detecting fraud.

In addition to paying attention to internal factors in itself, external auditors should also pay attention to potential factors that can lead to financial statement fraud by recognizing early signs of potential fraud. Recognizing the early signs of potential fraud The auditor can use the initial signal in assessing the risk of fraud in the form of a red flag. Knowledge of the understanding of the red flag becomes very important in assessing the risk of fraud [11]. [12] claim in their research that the red flags method is effective for use in detecting fraud. This finding is supported by [13]. Based on the results of previous studies, research on understanding red flags in detecting fraud has not been used with the experimental design and most of the red flag studies use surveys in assessing the perceptions of internal auditors and external auditors on the level of effectiveness of red flags in detecting fraud as has been done by [13] and [12].

Based on the researchers' view above, this study looks at two factors that influence the assessment of external auditors in assessing fraud risk, namely internal and external factors. Internal factors in the auditor for example in the form of professional skepticism and external factors in the form of an auditor's understanding of the red flag. With the factor of professional skepticism, auditors will be more sensitive to material misstatements caused by fraud, then become better at making fraud risk assessments [14]. While understanding the red flag with regard to the client's environment can be directed as an initial signal the auditor assesses the risk of fraud in detecting fraud.

The experimental method was used in this study because it was considered appropriate to answer research questions about causation and made it possible to measure professional skepticism and auditor behavior. The experimental model also allows researchers to manipulate to create situations or phenomena that are artificially desired to represent reality. therefore, the choice of audit perspective as a dynamic process and the use of experiments is expected to have high theoretical, practical and policy relevance [7].

This research is motivated by the inconsistency of the findings about the importance of fraud risk assessment in detecting fraud and the absence of experimental design to test the effect of understanding the red flag in assessing fraud risk. This study aims to empirically examine the effect of auditor professional skepticism and red flag understanding on fraud risk assessment in detecting fraud.

The novelty in this research is to develop a fraud risk assessment model by taking into account the auditor's external factors namely the client's environment in assessing the risk of fraud in an experimental study. Red flags are an initial signal for auditors to detect fraud, so this research can contribute to the additional literature in assessing fraud risk. Another contribution is that the government as a regulator can be used as a model in combating corruption, considering that in Indonesia the level of corruption index is still high.

\section{Literature Review and Hypothesis 2.1 Fraud Risk Assessment}

Fraud risk assessment is the process of assessing the risk of material misstatement in the financial statements caused by fraud [15]. [16] issued an audit standard (SA) Section 240 specifically requiring the 
auditor during the audit process to conduct fraud risk assessments in order to direct the objectives of the financial statement audit where this fraud risk assessment is a method to assist the auditor in determining the scope of audit procedures related to type and amount of fraud risk in an organization. External auditors conducting fraud risk assessments are a form of responsibility for preventing material misstatements due to fraud during the audit process [16]. Aside from being a form of auditor responsibility in order to prevent material misstatement due to fraud, fraud risk assessment can also be used as a tool against the auditor, if the auditor is exposed to future litigation risks relating to fraudulent financial reporting [15]. Furthermore [17] explains that auditors must play an active role to always dig up information about which parts of the financial statements or business processes are vulnerable to fraud. The auditor must specifically provide an assessment of the possibility of misstatement due to fraud. [11] states that to improve fraud risk assessments, external auditors can use the red flag in this case the client's narcissistic personality as an initial signal to conduct fraud risk assessments. On the other hand, red flags do not only observe personal client personalities, accountants should also pay attention to various client environmental conditions that have the potential to commit fraud. So thus the auditor should be able to understand the red flag not only observe the client personally but thoroughly as an early indication of danger signs in conducting fraud risk assessments [12].

\subsection{Professional Auditor Skepticism}

SA Section 200 states that auditors must plan and carry out audits with professional skepticism given that certain conditions may occur which cause financial statements to contain material misstatements. Professional skepticism also includes being aware of, among other things, audit evidence that conflicts with other evidence obtained, information that raises questions about the reliability of documents and responses to requests for information used as audit evidence, circumstances that indicate possible fraud, and conditions that suggest the need for audit procedures additional to the procedures required by the SA. In applying professional skepticism, the auditor does not assume that the client is dishonest, but does not also directly believe the information made by the company's management is true [16].

Furthermore, SA Section 240 states that to maintain professional skepticism, it is necessary to ask questions on an ongoing basis about whether the information and audit evidence that has been obtained provides clues that material misstatement due to fraud may occur. This includes considering the reliability of information that will be used as audit evidence and control over its preparation and maintenance, if relevant. Because of the characteristics of the fraud, the auditor's professional skepticism is important especially when considering the risk of material misstatement due to fraud. [6] illustrates that professional skepticism is a multi-dimensional individual characteristic. As an individual characteristic, professional skepticism can take the form of each innate trait (ie, a stable and enduring aspect of a person and also situational (state), ie a temporary condition caused by a particular situation. [15], auditor professional skepticism is needed to make decisions about how much and what type of audit evidence should be collected. Meanwhile, the phrases in the auditing process are the first, there is information and criteria that have been set. Second, gathering and evaluating evidence. Third, it is handled by competent and independent auditors. Finally, then prepare the audit report.

It can be explained from this, that skeptical auditors will continue to search and explore the available evidence so that it is sufficient for the auditor to carry out his work to audit, is not easy to believe and is quickly satisfied with what has been seen and presented in plain view. So that it can find errors or cheats that are material, and ultimately can provide the results of an appropriate audit opinion according to a picture of the actual state of a company.

\subsection{Red Flag Understanding}

The term red flags has often been used in a variety of audit literature, the meaning is a sign of danger, a sign that something is out of place and needs attention. [18] states that auditors and investigators use red flags as indications or indications of fraud or fraud in a financial statement. Red flags can also be regarded as an odd condition or different from normal conditions. In other words, red flags are instructions or indications of something unusual and require further investigation. Red flags do not absolutely indicate whether someone is guilty or not but are warning signs that cheating is or is happening. Red flags are said to be important as cited in Audit Standard 240 which states that the auditor 
is asked to specifically assess the risk of misstatement caused by fraud and also provide operational guidelines for the auditor when assessing fraud in the middle of the audit process.

[19] in Red Flags for Fraud states that many studies discuss fraud, where when fraud is occurring, red flags also appear, either in the company's financial statements, or seen when auditors are conducting audits, but are not aware of or may realized but no action was taken. DiNapoli said that when a red flag had appeared, someone had to take action to investigate the situation and determine whether fraud had taken place. Indeed, if there is an indication of fraud, an action is taken to check whether the indicated fraud has occurred, but sometimes misstatements in reports, changes in employee lifestyle, sudden sales volume increase, etc. do not always indicate fraud. For this reason, public accountants and auditors must be able to know the difference and remember that the responsibility for conducting follow-up investigations for a warning sign must be in the hands of people who can be trusted and responsible.

Detecting fraud is not an easy task because it requires comprehensive knowledge about the characteristics and ways to commit fraud. Fraud detection also does not always get a bright spot due to various underlying motivations, and the many methods of committing fraud [20]. The reasons above affirm that the auditor needs indicators or signs (red flags) to focus on performance in assessing fraud risk. Red flags are a potential symptom that requires deeper investigation, which indicates a higher risk of intentional misstatement in the financial statements. It can be said that red flags are an early warning signal so as to reduce the risk of fraud being not detected by the auditor.

\subsection{Hypothesis Development}

\subsubsection{Professional Auditor Skepticism and Fraud Risk Assessment}

Audit Standards (SA) Section 230 in Indonesia states that auditors must consistently question and evaluate existing audit evidence critically [16]. This standard also requires the auditor to be critical of all evidence during the audit process from the collection to evaluation stage. Skeptical auditors will continue to search and explore the available evidence so that the auditor is able to carry out his work to audit, is not easy to believe and is quickly satisfied with what has been seen and presented in plain view. So that it can find errors or cheats that are material, and ultimately can provide the results of an appropriate audit opinion according to a picture of the actual state of a company.

Previous research from [6] explains that skepticism from auditors influences auditor behavior, namely in the assessment of evidence and making alternative arguments. The assessment of evidence consists of the auditor's search for additional information, detection of contradictory information, and accidental errors [6]. Professional skepticism as an internal factor of an auditor is a critical thought to detect whether there is something unusual in the financial statements. Professional skepticism is formed by the personal character of each auditor. Therefore, professional skepticism possessed by each auditor has a different level from one another. Some auditors have a higher level of skepticism than others, which causes the auditor to have a tendency to doubt some of the statements made by the client.

The results of Husein's research [21] in the Big 4 and non Big 4 groups showed that professional skepticism and experience had a positive effect while time budget pressure had a negative effect on the auditor's assessment of the risk of material misstatement; and 4) The positive effect of professional skepticism on the auditor's assessment of the risk of material misstatement is stronger among more experienced auditors than less experienced ones. On the other hand, the positive effect of professional skepticism in risk assessment is weaker when auditors work under high time budget pressure than that when they work under low time budget pressure.

[22] in a survey study of 40 auditors in KAP Makassar obtained evidence that the perception of red flags and professional skepticism had a positive and significant effect on fraud detection. While the auditor's work experience has a positive but not significant effect on fraud detection. Red flags and auditor work experience have a positive and significant influence on professional skepticism. Professional skepticism is able to mediate the significant influence between red flags and auditor work experience on fraud detection.

Audit Standards Section 240 provides guidance for auditors to always maintain professional skepticism about the current audit regardless of previous experience with clients. However, a study from [3] revealed that prior experience significantly influenced the level of auditor skepticism to determine initial cheating or error rather than auditor skepticism of their nature. Furthermore, auditors who have a 
higher level of professional skepticism tend not to be influenced by previous experience with clients and maintain professional skepticism to determine initial fraud/errors.

Professional auditor's skepticism influences the auditor's decision on the risk of material misstatement contained in the client's financial statements [14]. [23] show that auditors with higher levels of professional skepticism are more sensitive to higher incidents of fraud and client narcissism positively influences the auditor's assessment of fraud risk. [24] also examined the positive effect of professional skepticism on increasing the ability to detect fraud. The study states that professional skepticism makes auditors seek additional information about the symptoms of fraud. Auditors who have a high level of professional skepticism will influence the auditor in assessing the risk of fraud in the report. Based on the arguments above, this study proposes the following hypotheses:

H1: Auditors with a higher level of professional skepticism tend to assess a higher risk of fraud than an auditor with a lower level of professional skepticism.

\subsubsection{Understanding Red Flag and Fraud Risk Assessment}

Red flags are the appearance of signs or symptoms that are not reasonable that occur in the environment and the attitude of someone who indicates the possibility of fraud so that further investigation is needed. Further analysis of the red flags by linking the Fraud Triangle Theory will help the auditor's next steps to obtain preliminary evidence in detecting fraud, whether the signal appears due to high pressure, the magnitude of the opportunity, or the existence of rationalization, so that later helps the auditor to focus the audit at the point that has a higher fraud risk so that it gets a higher priority to be audited [12] .

[25] in a study of 51 internal auditors in Brazilian credit institutions, found evidence that in the assessment of fraud risk by internal auditors that the most important attribute of the red flag refers to operational activities and internal control procedures. In addition, it is recommended that internal auditors are impartial about their perceptions about the relevance of most warning signs of possible fraud. [12] and [26] have a perception that the red flags method is effective for use in fraud detection. [27] also confirms the study which states that the higher the level of red flags found by an auditor in his audit assignment, the higher the ability of an auditor to detect fraud. The auditor in detecting fraud first assesses the risk of fraud. From the results of these studies, the following hypotheses can be drawn:

$\mathrm{H} 2$. Auditors with a higher level of understanding of red flags tend to assess fraud risk higher than auditors with a lower level of understanding of red flags.

\section{Research Methods}

\subsection{Participants}

This study uses an experimental method approach. The experimental participants in this study were S1 students majoring in Accounting, Faculty of Economics, Business and Tourism, Hindu University of Indonesia in Denpasar, Bali Province. Researchers consider the use of students because 1) the process of laboratory experiments is a fairly long process, so it is likely to involve auditors who actually will be very difficult to do. The determination of participants is based on certain criteria, namely S1 undergraduate students majoring in accounting who have already received Auditing 2 courses and received auditing training, thus it is expected to have insight in audit assessments, especially fraud risk assessments. 2) The effect of bias can be reduced especially with respect to the level of skepticism of those who have not been influenced by other parties.

\subsection{Experimental Design}

The type of experimental research used is pure experiment with a $2 \times 2$ factorial design between subjects (see table 1). Experiments were chosen in order to observe the causality relationship between the independent variable and the dependent variable with a high degree of accuracy. In this study can be identified into two independent variables namely professional skepticism and understanding the red flag which will later be tested for its effect on fraud risk assessment to detect fraud by external auditors. Participants were then divided into four different groups, with each group receiving a different exposure to manipulation through randomization. 
Table 1. Experimental Design

\begin{tabular}{llll}
\hline & & \multicolumn{2}{c}{ Red Flag Understanding } \\
\cline { 3 - 4 } & & Low & High \\
\hline Professional & Low & Sel 1 & Sel 2 \\
skepticism & High & Sel 3 & Sel 4 \\
\hline
\end{tabular}

The first stage of this experiment is to prepare the research instrument. The research instrument is a case that illustrates the behavior of auditors in assessing the risk of fraud adopted from [6] for professional skepticism, [28] understanding red flags and [11] for fraud risk assessment. The second stage before the actual experiment was carried out first carried out a pilot test conducted on ten accounting study students to get the quality of the instrument before doing the actual research. The third stage is the process of collecting data which is part of a real experiment. The implementation of this experiment was carried out in the classroom by controlling the environmental confounding variables in the experiment. Things that need to be considered so that the confounding variable does not affect the results of the experiment are the influence of the environmental conditions in which the experiment is controlled so that the environment is not noisy, a good microphone, cool air conditioner and comfortable seating and the influence of other factors such as mood and fatigue. This can be avoided by giving a prize to each participant. The experimental activities carried out in March-April 2019 with about 20 minutes to fill the questionnaire.

This study uses a questionnaire instrument in experimental activities which can be divided into 3 parts, namely the first part contains the demographic factors of participants consisting of age and sex. The second part contains measurements of the level of skepticism and understanding of red flags. The third part contains a fraud risk assessment from a case of The Beaumont Construction Company, a company that specializes in private and government projects.

\subsection{Operational Definitions of Research Variables \\ 3.3.1 Fraud Risk Assessment}

The measurement of the dependent variable in this study was carried out as a study conducted by [11] Fraud risk assessment as the dependent variable in the case scenario is measured by the following sentence: "Overall, I believe the risk of fraud in this business unit is .....

"Responses to fraud risk assessment questions are measured on a seven-point graph scale, where 1 shows" very low ", 7 shows" very high "and number 4 as the midpoint is labeled" medium "[11](Johnson, et al., 2013).

\subsubsection{Professional Skepticism}

Professional skepticism is measured using the [6]Hurtt scale (2010), the scale has been developed by including 6 characteristics of professional skepticism. The characteristics include questioning mind, suspension of judgment, search for knowledge, interpersonal understanding, autonomy, and self-esteem. The Hurtt Scale (2010) consists of 30 items of statements using a 6-point Likert scale, where the information includes strongly disagreeing, disagreeing, disagreeing, somewhat agreeing, agreeing, and strongly agreeing. Then the participants' answers are accumulated with a total total of 30 and a total of 180 , where total values above the median indicate a high level of skepticism while a total score below the median indicates a low level of skepticism.

\subsubsection{Understanding of Red Flag}

Red Flag understanding is measured using the Yanti scale (2013), the scale has been developed by entering 16 number of situational questions with dichotomous criteria namely True and False. The more participants answered correctly, the higher the score and it can be said that participants also accumulated with the lowest total value of 0 and the highest total value of 16 for each participant, where the total value above the median indicates a high level of understanding of the red flag while the total a value below the middle value indicates a low level of red flag. 


\section{Results and Discussion}

\subsection{Characteristics of Participants}

The total number of participants in this respondent were 60 people who came from accounting study programs at the Faculty of Economics, Business and Tourism, Hindu University of Indonesia. Twelve questionnaires cannot be processed because the participant did not follow orders or the filling did not follow procedures. So that the total data that can be analyzed is 48 participants. Next, the following participants' characteristics are presented in more detail in table 2 as follows:

Table 2. Characteristics of Participants

\begin{tabular}{lccc}
\hline \multicolumn{1}{c}{ Characteristics } & Level & Frequency & Percentage \\
\hline Age & $15-20$ years & 0 & 0 \\
& $21-25$ years & 48 & $100 \%$ \\
& $26-30$ years & 0 & 0 \\
Amount & $31-35$ years & 0 & 0 \\
Gender & & $\mathbf{4 8}$ & \\
& Male & 21 & $43,75 \%$ \\
Amount & Female & 27 & $56,25 \%$ \\
Skepticism & & $\mathbf{4 8}$ & \\
& Low & 22 & $45,83 \%$ \\
Amount & High & 26 & $54,17 \%$ \\
Red Flag understanding & & $\mathbf{4 8}$ & \\
& Low & 21 & $43,75 \%$ \\
Amount & High & 27 & $56,25 \%$ \\
Experiment Group & & $\mathbf{4 8}$ & \\
& Sel 1 & 13 & \\
& Sel 2 & 13 & \\
Amount & Sel 3 & 14 & \\
\hline
\end{tabular}

Based on table 2 it can be explained that the participants of this study were dominated by students with ages between 21 years and 25 years. In addition, in this study, participants with female more than men.

\subsection{Hypothesis Testing and Interpretation}

The hypothesis that has been developed is tested using two ways Analysis of Variance or better known as ANOVA. Testing using ANOVA in this study was carried out using a significance level of 0.05 . Both hypotheses that have been developed will be tested using the two-way ANOVA method because there are two independent variables.

\subsection{Professional skepticism}

The results of testing the first hypothesis in Table 3, show the results of $F=5.287$ and a significance value of 0.014 . This means that the average participant who has a high level of professional skepticism tends to provide a higher risk of fraud when compared with participants who have a low level of professional skepticism. The results of this statistical test support hypothesis 1 (H1) which states that auditors with a higher level of professional skepticism tend to assess a higher risk of fraud compared to auditors with a lower level of professional skepticism.

Table 3. Two-way ANOVA Test Results

\begin{tabular}{lcc}
\hline \multicolumn{1}{c}{ Hipotesis } & F & Sig \\
\hline H1 & 5,287 & $0,00,014^{*}$ \\
High Skepticism > Low Skepticism & & \\
H2 & 3,654 & $0,028^{*}$ \\
\hline High Red Flag > Low Red Flag & & \\
\hline
\end{tabular}

* Significant at $\alpha=0.05$; Source: Data processed 
Apart from the various limitations encountered when carrying out the audit function, auditors are always expected to provide quality audits. Therefore, auditors need to maintain their professional skepticism wherever they are so that every audit process that is carried out is of high quality [4] (Nelson, 2009). One effort to provide quality audit results is the accuracy of the auditor in assessing the risk of fraud, here this assessment depends one of them on professional skepticism as an internal factor.

Professional skepticism from auditors is important for assessing the risk of fraud. Through professional skepticism, auditors are increasingly sensitive to the possibility of material misstatement caused by fraud. Then the auditor improves the assessment of fraud risk by increasing or decreasing the level of existing risk. Previous research from [6]Hurtt, et al. (2010) explains, skepticism from auditors influences auditor behavior, namely in evaluating evidence and making alternative arguments. Which the assessment of evidence consists of the search for additional information by the auditor, the detection of contradictory information, and unintentional errors [6] (Hurtt, et al., 2010)

For professionals in Indonesia, this research can provide input on the importance of professional skepticism for auditors. Through regulation or other authority possessed by the profession, this factor of professional skepticism should be regulated in more depth. For example with the obligation of training for auditors with training material specifically training professional skepticism of auditors. Or setting more detailed standards about the extent to which auditors must optimize professional skepticism that is owned for the audit process to be effective and efficient.

\subsection{Understanding of Red Flag}

The results of testing the second hypothesis in table 3 , shows the results of $\mathrm{F}=3.654$ and a significance value of 0.028 . This means that the average participant with a high level of understanding of red flags will provide a higher risk of fraud when compared to participants with a low level of understanding of the red flag. The results of this statistical test support hypothesis 2 (H2) which states that Auditors with a higher level of understanding of red flags tend to assess the risk of cheating higher than auditors with lower levels of understanding of red flags.

The results of this study illustrate that the existence of an understanding and knowledge of the existence of a red flag will make it easier for auditors to set the steps to be taken in examining fraud and can immediately take preventive action [27 (Prasetyo, 2015). Suspicion arising from signs of fraud is one indication that will enable the auditor to focus more on his performance to obtain accurate and relevant information about the fraud that occurs. Increased awareness of the emergence of red flags will make auditors conduct a deeper search or investigation of audit evidence, this can make the auditor's ability to detect fraud increasingly high [29] (Purwanti and Astika, 2017). These results support the statement [13] (Kassem and Higson, 2012) which explains that in carrying out their duties, external auditors need a good understanding of fraud opportunities that are needed so that external auditors can be helped to process the identification of various fraud schemes. it can do and how to take the risk of fraud.

With the relationship between understanding red flags and enhancing fraud risk assessments, this finding can be a consideration for auditors to better understand and pay attention to the red flags around the client's environment as a starting signal, even though in reality it may not necessarily be real.

\section{Conclusions and limitations}

The results show that fraud risk assessment is influenced by internal and external factors within the auditor. Where the internal factor in the auditor is professional skepticism and the external factor is the understanding of the red flag. This finding shows that the higher the professional skepticism and understanding of an auditor's red flag, the higher the fraud risk assessment.

This research is inseparable from the limitations of the study and should be considered for further research. The limitation is to use undergraduate students as participants so that the results of this study cannot be generalized to all auditors in Indonesia, and the manipulation of red flags is limited to understanding only by not observing directly how the red flag is.

Given the limitations that have arisen in this study, greater opportunities are available for further research to corroborate existing findings or even provide new findings. Some suggestions for further research from researchers include further research should use actual auditor participants, so the results of subsequent studies provide more generalizable information to all auditors in Indonesia. Furthermore, 
further research can also use auditor participants who already have a widely recognized professional certification. Then, further research can use more interactive research instruments not only limited in the form of case questionnaires so that participants can take the experiment seriously from the beginning to the end of the study.

\section{References}

[1] C. A. Knapp and M. C. Knapp, "The effects of experience and explicit fraud risk assessment in detecting fraud with analytical procedures," Accounting, Organ. Soc., 2001.

[2] T. D. Carpenter, "Audit team brainstorming, fraud risk identification, and fraud risk assessment: Implications of SAS No. 99," Account. Rev., 2007.

[3] V. Popova, "Exploration of skepticism, client-specific experiences, and audit judgments," Manag. Audit. J., 2013.

[4] M. W. Nelson, "A model and literature review of professional skepticism in auditing," Auditing, 2009.

[5] E. A. Payne and R. J. Ramsay, "Fraud risk assessments and auditors" professional skepticism," Manag. Audit. J., 2005.

[6] K. K. Hurtt, M. M. Eining, and D. Plumlee, "An Experimental Examination of Professional Skepticism," SSRN Electron. J., 2011.

[7] R. W. Anggoro, "Pengaruh Latar Belakang Pendidikan, Tekanan Waktu, dan Sanksi Terhadap Skeptisisme Profesional Auditor," 2015.

[8] G. S. Castro, "Internal auditors skepticsm in detecting fraud," 2013.

[9]S. Pretnar Abičić, "Professional Skepticism of Auditors And Risk Of Fraudulent Financial Reporting," J. Account. Manag., 2014.

[10] R. Suryanto, Y. Indriyani, and H. Sofyani, "Determinan Kemampuan Auditor dalam Mendeteksi Kecurangan," J. Akunt. dan Investasi, 2017.

[11]E. N. Johnson, J. R. Kuhn, B. A. Apostolou, and J. M. Hassell, "Auditor perceptions of client narcissism as a fraud attitude risk factor," Auditing, 2013.

[12]G. D. Moyes, R. Young, and H. F. M. Din, "Malaysian internal and external auditor perceptions of the effectiveness of red flags for detecting fraud," Int. J. Audit. Technol., 2013.

[13] 1 Mohamed Abd El Aziz Hegazy and R. Kassem, "Fraudulent financial reporting: do red flags really help?," J. Econ. Eng., vol. 1, no. 4, pp. 69-79, 2010.

[14] D. Fatmawati, A. Mustikarini, and I. P. Fransiska, "Does accounting education affect professional skepticism and audit judgment?," J. Pengur., 2018.

[15] A. A. Arens, R. Elder, and M. S. Beasley, "Auditing and Assuranc Services, an Intergrated Approach," Prentice Hall, Pearson. 2005, 2005.

[16] Institut Akuntan Publik Indonesia, "Standar Audit," in Standar Audit, 2013.

[17] L. W. Vona, "Program Management Fraud," in The Fraud Audit, 2012.

18] T. M. Tuanakotta, Mendeteksi Manipulasi Laporan Keuangan. 2013.

[19 ]T. P. DiNapoli, "Red Flags of Fraud,” Essentials Corp. Fraud, 2008.

[20] R. Kassem and A. Higson, "The New Fraud Triangle Model," J. Emerg. Trends Econ. Manag. Sci., 2012.

[21] S. A. H. Sayed Hussin, T. M. Iskandar, N. M. Saleh, and R. Jaffar, "Professional skepticism and auditors' assessment of misstatement risks: The moderating effect of experience and time budget pressure," Econ. Sociol., 2017.

[22] S. R. M. M. Asbi Amin, "Red Flag And Auditor Experience Toward Criminal Detection Trough Profesional Skepticism,” J. Akunt., 2019.

[23] R. Djatu Winardi, A. Mustikarini, and Y. Permana, "Do Auditor Professional Scepticism and Client Narcissism Affect Fraud Risk Assessment?,” Indones. J. Account. Res., 2017.

[24] H. Nasution, "Pengaruh Beban Kerja, Pengalaman Audit, Tipe Kepribadian Terhadap Skeptisme Profesional dan Kemampuan Auditor dalam Mendeteksi Kecurangan,” 2012.

[25] C. B. D. Magro and P. Da Cunha, "Red flags in detecting credit cooperative fraud: the perceptions of internal auditors," Rev. Bus. Manag., 2017.

[26] E. Yücel, "Muhasebe ve Finansman Dergisi Effectiveness Of Red Flags in Detecting Fraudulent Financial Reporting: An Application In Turkey,” J. Account. Financ., 2013. 
[27] S. Prasetyo, K. -, and R. Hanif, "Pengaruh Red Flags, Skeptisme Profesional Auditor, Kompetensi, Independensi, Dan Profesionalisme Terhadap Kemampuan Auditor Dalam Mendeteksi Kecurangan (Studi Empiris Pada Kantor Akuntan Publik Di Pekanbaru, Padang, Dan Medan Yang Terdaftar Di Iapi 2013)," J. Online Mhs. Fak. Ekon. Univ. Riau, vol. 2, no. 1, 2015.

[28] H. B. Yanti, "Pemahaman Auditor Tentang Skema Kecurangan, Red Flags, Mekanisme Deteksi Dan Mekanisme Preventif Kecurangan," Media Ris. Akuntansi, Audit. dan Inf., 2017.

[29] I. G. Ayu et al., "Pengaruh Auditor' S Professional Skepticism , Red Flags , Beban Kerja Pada Kemampuan Auditor Dalam Mendeteksi Fraud Fakultas Ekonomi dan Bisnis Universitas Udayana ( Unud ), Bali , Indonesia Fakultas Ekonomi dan Bisnis Universitas Udayana ( Unud ), Bali ," E-Jurnal Akunt. Univ. Udayana, vol. 21, pp. 1160-1185, 2017. 